\title{
Hospitalidad y resistencia de las lenguas nómadas.
} Acerca de De nomadismos y hospitalidades.

Comcaac y saharauis

\section{Hospitality and Resistance of Nomad Languages.}

About De nomadismos y hospitalidades.

Comcaac y saharauis

\author{
Andreas Ilg \\ Universidad Nacional Autónoma de México \\ Universidad Iberoamericana \\ ilgandre@gmail.com \\ orcid.org/oooo-0002-8688-1229
}

Resumen: El título del presente ensayo se cristalizó como "rosa del desierto" desde los minerales de una reseña sobre el libro De nomadismos y hospitalidades. Comcaac y saharauis. Inspirado en sus sendas y texturas, reflexiona sobre el nomadismo fundamental en todas las lenguas, un nomadismo que -nos lo enseñan los pueblos que lo practican - se basa en la hospitalidad y la resistencia. He aquí un ejercicio poético que alcanza los espacios de la política y de la filosofía del lenguaje, y que las acaricia y roza como el viento desértico a las figuras que nombra y el rostro humano que las expresa.

Palabras clave: lenguas, nomadismo, hospitalidad, resistencia, comcaac, saharauis

Abstract: The title of the present essay crystallized as a "desert rose" from the minerals of a review of the recently published book De nomadismos y hospitalidades. Comcaac y saharauis. Inspired by its paths and textures, it reflects on fundamental nomadism in all languages, nomadism that - as the people who practice it teach us - is based on hospitality and resistance. This essay is a poetic exercise that reaches the spaces of politics and the philosophy of language, and caresses and chafes them like the desert wind that carves the figures it names and the human faces which express them.

Keywords: $\quad$ languages, nomadism, hospitality, resistance, Comcaac, Saharawi 
Recibido: $\quad 15$ de octubre de 2019

Aceptado: $\quad 28$ de noviembre de 2019

Solitario es el extranjero, vocablo desarraigado. Sin embargo, basta que otro vocablo se una a él para que el libro tenga oportunidad de ser libro.

Edmond Jabès

¿Cuáles son las lenguas nómadas? ¿Cómo, de qué y ante quiénes resisten? ¿Cuál es la hospitalidad que las habita? ¿Las habita? ¿De qué forma y sobre qué trama de sus andanzas?

El viaje al que estas preguntas inspiran parte de un encuentro alegre y asombroso con un libro de mediano formato que, bajo el brazo, me acompañaba en varias de mis caminatas, ${ }^{1}$ y que, en las pequeñas paradas que hacía, me sorprendía y refrescaba con sus imágenes y palabras, en el cual operaban, y operan cada vez de nuevo, los secretos mecanismos de constelaciones y de ensamble.

Uno de estos ensamblajes es el alegre sintagma: "libro pop-up académico" (Rabinovich 2019: 4). Efectivamente, he aquí un "libro pop-up" cuya escritura gira y se acomoda cuidadosamente a modo de volvelles alrededor de imágenes de ancianos y niños, poetas y activistas que se alzan como móviles solapas; en derredor de fotos emergentes de paisajes y resistencias; $y$ en torno de tantas miniaturas, objetos varios que por aquí y por allá saltan a la vista como pequeñas pestañas. Pero también es un exótico montaje de palabras que precisamente da cuenta de un nomadismo de las lenguas que no es exclusivo de las que hablan los pueblos nómadas, sino que habita y atraviesa, inquieto y juguetón, toda lengua, y conmueve y agita todo encuentro entre lenguas. Aquí son el español y el inglés, cuyas raíces, como si fueran las de un pequeño arbusto estepario, se extienden al anglosajón, latín y griego, y cuyo trémulo follaje susurra onomatopeyas en el viento. También es una constelación lúdica de letras, de las que solo las sonoras $p$ atraviesan la invisible superficie del renglón en busca de arraigo. Y es un encuentro entre lo emergente de un

1 Alusión a una obra del poeta egipcio Edmond Jabès: Un extranjero con, bajo el brazo, un libro de pequeño formato. 
pop que surge de repente, y lo estable y firme de un adjetivo milenario. Es conjugación de una gramática paratáctica y fuga súbita de un sonido; como la risa de un niño que corre por los abovedados pasillos de un edificio antiguo de la universidad. Es la paradoja de la civilización sedentaria y de un móvil transitar.

De nomadismo y hospitalidades. Comcaac y saharauis (Rabinovich 2019) es un libro por el cual el lector, niño con rostro iluminado, no solo se pasea sino en cuyas telas se sumerge, volviendo permeable el español escrito con las impresiones y resonancias de los tejidos gráficos y de las lenguas del cmiique iitom y del hassanía. De esta manera, este libro se convierte en una jaima (Rabinovich 2019: 10), tienda de campaña saharaui, o un haaco haeemza (Rabinovich 2019: 20), vivienda tradicional comcaac. Pues, de alguna manera, desplegaba un mundo de colores y de sonidos donde cada parada de mis caminatas encontraba su transitoria morada.

Y este despliegue estético nos enseña que a este nomadismo de las lenguas le habita una hospitalidad que invita a convivir y a conversar a culturas muy diferentes, asaz distintas incluso que, en su extranjería idiomática, estremecen y agitan las referencias lingüísticas tan familiares de nuestros mundos. Con cada página que alzamos, el campo policromático y multiforme del libro, plegado tejido plurilingüe, se nos entrega como el espacio aromático y cálido, cuando se nos levanta la kayfa (Rabinovich 2019: 40) con el gesto hospitalario de sumarse a la reunión del té.

También nos enseña que este espacio, hecho de telas extendidas sobre pilares enlazados por cuerdas atadas al suelo, es frágil, como sutiles y móviles son las articulaciones de las palabras saharauis que denominan a cada uno de sus componentes: el nombre rkaiz, para designar a los pilares; hamar, a las cuerdas; akhwalef, a las brocas que las atan al piso; y la susodicha palabra, kayfa, en la que resuenan Las mil y una noches. El espacio que en trabajo comunitario o tuiza (Rabinovich 2019: 40) erige y sostiene estos objetos, constituye una intimidad vulnerable que puede fácilmente ser profanado por otro incapaz de corresponder con el humilde reconocimiento de su propia vulnerabilidad. Al contrario, esa correspondencia es la del extranjero cual suplicante del que Maurice Blanchot dice que es "aquel que viene"; aquel que siempre está "en marcha por carecer de lugar" (Blanchot 2008: 118). Esta carencia de lugar es también la que habita y vuelve nómadas a las palabras, pues también ellas pueden ser proferidas por intenciones que no buscan el encuentro, sino que se empecinan en la usurpación y la conquista, en el su- 
puesto poder que la posesión de la palabra les confiere. Ningún libro, ninguna palabra está a salvo de este vilipendio, ninguna lengua se sustrae de estos atropellos. Si "la Biblia se quema por los abusos que padecen algunas de sus figuras al servicio de un discurso militarista", proyecta, no obstante, sus fantasmas, que recorren el hebreo moderno (Rabinovich 2013: 19, 23). Pero también al discurso del poder el juego de la lengua lo subvierte. Lo que se quiere decir, situando y sitiando la palabra en un lugar, siempre se refracta en resonancias diversas y errantes espectros por la carencia de lugar, la del suplicante, la del extranjero. También son los fantasmas que recorren todo discurso y que habitan toda lengua, fantasmas que asedian las tentativas de posesión y que, umbrosos y gimientes, estremecen con asombro y espanto a las moradas diurnas donde reside la razón o, noctívagos y musitantes, a los campos oníricos en los que duerme. Y así, por un instante, el asombro hace de la razón un huésped y del sueño un suplicante (Derrida y Dufourmantelle 2006: 38, 40). Es "aquel que viene" y son aquellos que vuelven, en, por y a través de las lenguas. Hospitalarias y resistentes.

Y así, volvamos a abrir el libro que llevamos bajo el brazo. Como en el caso de la jaima saharaui y la aparentemente más frágil morada comcaac, ante las tempestades y duros vientos del desierto, así como ante los abusos intencionales de la lengua, los artefactos tallados en palo verde o tejidos de torote o "haat" (Rabinovich 2019: 20) resisten como resisten las palabras. Su resistencia, como la hospitalidad que habita las lenguas, toman ambas la fuerza y suavidad de quienes las ejercen.

En la portada del libro sobre los comcaac y saharauis, los rostros de doña Ramona Barnett y de Brahim Bahia Ahmed se acercan, casi se ponen cara a cara, y representan el encuentro con el otro por medio de un puente que para ambos pueblos nómadas, comcaac y saharauis, es la lengua española. También para nosotros, que miramos, abrimos y nos adentramos en el libro, visitando su vulnerable intimidad. No obstante, el español, como frágil línea, guion delgado que atraviesa dos tierras lejanas, se aviva con el soplo de esas lenguas distintas, y se esculpe - como el alma - con esos vientos de dos desiertos. Ambas culturas, como este libro que los acoge, abren sus recintos para dar la bienvenida al extranjero. Y ambas culturas, cuyas esperanzas y luchas quedan inscritas en los pliegues y surcos de dos rostros, hablan de esas resistencias que en territorios amenazados por los excesos de la civilización sedentaria crean su "república en el exilio" (Rabinovich 2019:3). 
Así que a una poética de la lengua se suma la política de la palabra, el ejercicio lingüístico del nomadismo y de la hospitalidad que, dando "acogida" - palabra carísima a Emmanuel Lévinas - y abriéndose así a la alteridad, no excluye a "la guerra, el rechazo, la xenofobia [que] implican que tengo que ver con el otro y que, por consiguiente, ya estoy abierto al otro" (Derrida 2001: 51). Pero esta cuestión política o "las políticas de la alteridad en el espejo del lenguaje" se basan en esa "ética espectral del otro" (Rabinovich 2013: 118). Y esta ética se mueve en los quicios del tiempo y sobre los umbrales del encuentro, en las articulaciones que conjugan y separan, convocan y realzan las "diferencias en la identidad". Homi Bhabha acuñó el feliz término de "disemiNación” (Rabinovich 2013: 118), que no aplana en "uno" la multiformidad y plurivocidad de los muchos que también son las lenguas. En esa ética espectral —pues no solo es la del otro vivo sino también la de los muertos, de aquellos que aún claman escucha y buscan morada - somos nosotros que con ellos conversamos en las lenguas que traducimos — recordando con Jean-Bertrand Pontalis que "traducir es reencontrar lo extranjero en el lenguaje" (Rabinovich 2017: 11)—; con esta ética se conjugan las poéticas y políticas en el montaje nómada que no erige sus edificios, ruinas del futuro, sino las carpas móviles del transitar. Transeúntes que vagamos por las lenguas y pasajeros que recorremos los pliegues de una obra, nos exponemos, ante todo, una y otra vez y cada vez de nuevo, al asombro.

Y, de repente, hallamos otro montaje sobre el umbral de las culturas y en las fronteras territoriales: es la imagen comentada del Caballo de Troya en el Sáhara Occidental, frente al muro impuesto por Marruecos. Es una escultura del artista mexicano Rolando de la Rosa, construida con desechos de la guerra: granadas de fragmentación, pedazos de jeep, cartuchos de balas y tambos de gasolina (Rabinovich 2019: 32). El libro sobre los saharauis y comcaac nos sorprende asimismo con objetos del despojo territorial de la descolonización inacabada en los campos de refugiados en Argelia o de la colonización y las violencias del Estado en la sierra de Sonora (Rabinovich 2019: 27).

El hecho de que nos sensibilicemos en los quicios entre los objetos-palabras, objetos-imágenes que hallamos con asombro - el caaz para la pezca y la gadha para la leche de camello-, permite contrastar, por un lado, canastas finamente elaboradas con fibras de torote (haat), tejidas en espiral y que, impermeables, posibilitan la carga de líquidos; por el otro, una oxidada mina de contacto, desenterrada del territorio invadido, que parece ser un amortiguador. Y esta última palabra nos devela que precisamente no es un dispositivo 
mecánico que sirve para compensar o disminuir el efecto de choques, sino que los produce con estallido mortal.

Lo multifuncional de aquellos artefactos del nomadismo y de la hospitalidad, en tajante contraste con este último objeto-palabra de la mina que los impide, nos recuerda que las palabras que dan acogida surgen de las lenguas a las que también habita el nombre de la guerra, el rechazo, la xenofobia. Pero los diversos usos y abusos nos vuelven a llevar a la polisemia de las palabras. Y las páginas que ya volteamos nos invitan a dejarnos seducir de nuevo. Ahora son las metáforas: el dromedario como "barco del desierto" (Rabinovich 2019: 12) y la puesta mineral en flor de agua, yeso y arena, de la "rosa del desierto" (Rabinovich 2019: 10).

Y de esta manera, no podemos impedir que estos barcos y rosas, que navegan y crecen como imágenes y letras de la trashumancia y la hospitalidad, se tropiecen y compartan su frágil vida con la amenaza del destierro con minas, muros y armamento. Ya dijimos que los dos rostros de la portada, tallados por el calor y el viento, también expresan la preocupación y transcriben décadas de resistencia. A ellos se suman las presencias de Gabriela Molina, Francisco Molina y Zara Monrroy (Rabinovich 2019: 28, 29). Y, una y otra vez, resuena, en epígrafes, la voz del poeta palestino Mahmud Darwish con el Discurso del Indio, franqueando los móviles confines del Sáhara Occidental y el Hant Comcaac, llevándonos así allende cualquiera de nuestras fronteras ideológicas, pues, en el fondo sabemos, y tras el recorrido por el libro De nomadismos y hospitalidades constatamos, que este mundo que somos capaces de dividir y rajar es una gigantesca jaima que bien puede darnos cobijo y alimento en compañía con quienes transitamos frágiles y vulnerables por esta tierra y con quienes preparamos y compartimos los aromas de la bienvenida.

Las últimas páginas del libro nos despiden conjugando los rituales del té con las instalaciones de la resistencia, equipándonos ahora para nuestro viaje fuera de la obra, inspirados con nuevas palabras y estremecidos nuevamente con nuestra fragilidad humana. Y nos despiden para volvernos a recibir cuantas veces queramos. De esta manera, este libro es el colorido reflejo del vivo e incansable intercambio de enseñanzas e ideas, cuyo espacio Heteronomías de la justicia ${ }^{2}$ nos recuerda que también la universidad es lugar y morada en

2 Proyecto que hace muchos años comenzó con el recorrido de "heteronomías de la lectura”, y que en 2017 condujo la conversación ininterrumpida entre lenguas y culturas a la obra Retornos del Discurso del "indio" (para Mahmud Darwish). 
nuestra andanza de "nomadismo y hospitalidad en el lenguaje", donde la voz propia se sorprende de la alteridad con la que se constituye.

Así el feliz nombre hispanizado del "turbante". El objeto al que denomina no solo protege la cabeza contra los rayos ardientes del sol del desierto, y cubre nariz y boca contra el polvo levantado por duros vientos, además de ser cálido cobertor por las noches. Entre sus mil y un usos hay uno que me atrajo y sedujo al instante: se lo desenrolla para tenderlo hacia lo hondo de un pozo que, tras una larga caminata, se halla en las áridas tierras de roca y de arena. La larga chalina alcanza así la superficie líquida que a veces yace a metros de profundidad y la tela absorbente se hincha de agua potable (Rabinovich 2019: 13). Una vez recogido, el turbante extendido, se lo exprime para entregar el anhelado tesoro que da vida. Reanima un cuerpo en fatiga e inspira pasos frescos de aventura. Y, vuelto a ser colocado sobre la asaz soberbia testa, templa sus delirios y sus ímpetus calma.

Como palabra en hassanía, el zam (Rabinovich 2019: 13) se desliza y enrolla con suavidad en derredor de los recintos de la razón y de la lengua, y desde el persa arriba y se inserta con voz turbante, sustantivo que se vuelve adverbio y se conjuga con una palabra de origen latino para devenir metáfora: voz turbante que turba, suave pero siniestra, las familiaridades nuestras, y enturbia, sorprendiendo y alterando, nuestras a menudo pequeñas certezas.

Si la voz e imagen de un objeto me llevo, si una palabra me acompaña ahora, es el acaiij, zumbador comcaac. Se refiere a un instrumento que, antes de entrar a las cuevas, se hace sonar "para pedir permiso a los espíritus. Su sonido además aleja a los espíritus malignos que pueden estar en la cueva" (Rabinovich 2019: 16). Para los caminos del porvenir se habrá empleado en forma de un gesto trémulo y humilde que pide permiso en cada estancia transitoria de una continua práctica dialógica con el otro, y que, crítico y decidido, denuncia todo aquello que asedia y amenaza a esta práctica. Lo hará con su nombre extranjero y con la modestia del suplicante.

\section{Bibliografía}

BlanchOт, Maurice (2008). "La medida, el suplicante”, La conversación infinita, trad. Isidro Herrera. Madrid, Arena: 117-120.

DerridA, Jacques (2001). ¡Palabra!, trad. Cristina Peretti y Paco Vidarte. Madrid, Trotta.

Derrida, Jacques, y Anne Dufourmantelle (2006). La hospitalidad, trad. Mirta Segoviano. Buenos Aires, Ediciones de la Flor. 
Jabès, Edmond (2002). Un extranjero con, debajo del brazo, un libro de pequeño formato, trad. Cristina González de Uriarte y Maryse Privat. Barcelona, Galaxia Gutenberg.

Rabinovich, Silvana (2013). La biblia y el drone. Sobre usos y abusos de figuras bíblicas en el discurso político de Israel. México, Iepala.

Rabinovich, Silvana (ed.) (2017). Retorno del Discurso del "indio" (para Mahmud Darwish). México, Universidad Nacional Autónoma de México/APOFIS de Fara Ediciones.

Rabinovich, Silvana (ed.) (2019). De nomadismos y hospitalidades. Comcaac y saharauis. México, Universidad Nacional Autónoma de México.

\section{Andreas Ilg}

Es licenciado en Psicología por la UNAM. Obtuvo la Maestría y el Doctorado en Literatura Comparada por la UNAM. Ha sido docente por alrededor de 20 años en diversas instituciones, principalmente en la UNAM y la UIA, además de la Universidad del Claustro de Sor Juana, 17 Instituto de Estudios Críticos, Colegio de Psicoanálisis Lacaniano, y Dimensión Psicoanalítica, A. c. Es autor del libro Hamlet. Entre el duelo y el deseo, México, Siglo XXI, 2018. Psicoanalista en práctica privada. 